\title{
Can Electronic Reverse-Auctions Destroy Business Relationships?
}

\author{
William R. Smith, Jr., Pepperdine University
}

\begin{abstract}
The fast-paced world of business in the early twenty-first century has created ever decreasing time periods between the waves of cycles. This phenomenon can lead to dramatic changes in prevailing practices in very short periods of time. In fact, it almost appears that management thought leaders are in direct conflict in some situations. Such a shift has occurred in recent years in terms of thoughts about the relationships between business buyers and sellers. Japanese businesses lead the movement towards trust-based relationships becoming sole-source arrangements in the 1980's. Management gurus worldwide were applauding this practice. By the late 1990's the antithesis was occurring as thought leaders began advocating not only the avoidance of sole-sourcing but the use of what could be viewed as a practice that made long-term relationships between buyers and sellers impossible. This was the dawning of the era of the electronic reverse auction. Is this a good thing or a curse?
\end{abstract}

Keywords: reverse-auctions, business relationships

\section{INTRODUCTION}

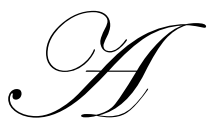

s Japanese businesses such as Toyota and Sony evolved into worldwide industry leaders in the 1970's and 1980's, management gurus created a steady stream towards Japan in order to study the reasons for this amazing success. One business practice that was commonly observed was the building of long-term relationships between buyers and suppliers that were built on trust. One part of the concept was that this type of trust-based relationship would lead to greater efficiencies for both partners, thus creating a winwin relationship. As the supplier got to know the needs of the buyer ever-more intimately, its ability to provide superior products and services to the buyer was greatly enhanced. This was viewed as an enlightened approach to management that would pave the road to long-term success with gold.

However, something strange happened on the road to Nirvana. The performance of the Japanese economy, as evidenced by its flagship companies, began to falter. Managers and their gurus from around the world began to question practices that had routinely been advanced as factors in the unparalleled rise of the Japanese economy. One of those practices was the idea that building trust-based relationships with the natural evolution into sole-sourcing with these preferred suppliers would allow buyers to improve their performance. This notion began to fall out of favor, especially with managers in the function that had long been referred to as "purchasing." As more and more leading Japanese firms began to falter, there became an ever-increasing drumbeat for a return to the days of strong focus on cost controls and reductions. This focus on costs was a welcome change to many "purchasing professionals" as it seemed to be emphasizing the importance of their domain. In fact, many "purchasing agents" felt they deserved a more prominent place at the table reserved for the strategic decision makers of the company. This was reflected by an evolution from having a function that was referred to as something like "purchasing management" into one that became something like "strategic sourcing." The philosophical shift that seemed to be occurring was that perhaps it wasn't possible to structure and maintain "win-win" relationships between vendors and buyers and that this interaction was, by nature, adversarial and a zero-sum game.

As the winds of change blew around the world, this evolution began to become a sea-change. The purchasing/procurement/sourcing managers were intent on adopting practices that would result in their 
suppliers/vendors understanding that the buyer had the power and would use it regularly to force price concessions. This was also occurring in the midst of the "electronic revolution," thus setting the stage to blend the use of buyer power with the ability of electronic communication to attract the interest of more sellers into something that would become known as the electronic reverse auction. Rather than buyers bidding to acquire something, sellers would bid for the right to sell something. The idea from the standpoint of the buyers (purchasing professionals) was that there would be major cost savings resulting from this competitive bidding process.

Initially, the reverse auction process was utilized for commodity-type products such as computer chips. However, as buyers began to see price reductions for these types of products, there developed something akin to a feeding frenzy. Ultimately, many buyers became so enamored of reverse auctions that they became convinced that even highly customized products could be purchased using this tool. As costs were driven lower and lower, the profile of the professional purchaser was raised higher and higher. This process fed on itself until one observer wrote that, "They're [Dell] trying to extend the process they use for buying memory chips and LCD screens to professional services." (Business Week, September 4, 2006, page 28). In this case, Dell was utilizing a reverse auction approach to contracting for recruiting services to perform this vital, and highly customized, HR function. It seemed to indicate a company gone mad with an obsessive focus on wringing costs out of its operations.

So, where will the wheel stop spinning: will we see a re-emergence of trust-based relationships with buyers being willing to trust sellers to pursue their mutual best interests or will we see an even stronger emphasis on the use of what some term a "coercive" process for forcing price reductions out of dependent sellers? (Giampietro and Emilani, 2007).

Nagle and Hogan go on to identify the following approaches to segmenting markets for the purpose of building pricing fences: (1) by purchase location, such as different prices for water on the beach versus at a supermarket some distance from the beach, (2) by time of purchase, such as midday movie matinees, (3) by purchase quantity, (4) by product bundling, such as a lower price for a mobile phone when it's bundled with service, (5) by tie-ins and metering, such as Hewlett-Packard having low margin prices on their printers but much higher margins on the replacement ink cartridges that are tied to the printer, and (6) by product design, such as Microsoft having a lower priced version of Windows that does not have the full functionality of the higher priced version.

\section{A LITTLE MORE ANCIENT HISTORY}

Managers have struggled for centuries (if not millennia) with the challenge often referred to as "reinventing the wheel" or sometimes stated as "there's nothing new under the sun." The current topic is another interesting case study surrounding this problem. Giampietro and Emilani (2007) point to some fascinating writings from the early twentieth century that speak to this notion that buyers should be intent on achieving cost reductions by browbeating their suppliers into price concessions. Some of the more interesting quotes referenced by Giampietro and Emilani are:

"The most important object in making any purchase is to obtain the right article, ..., that article which is best suited to meet the buyer's requirements... yet ninety-nine purchasing agents out of ninety-nine work on the theory that price is the most important consideration." Purchasing by C.S. Rindsfoos, 1915, p. 1

"If you treat them [suppliers] fairly, they will treat you fairly... he [the buyer] must establish relationships of good will [sic] and mutual confidence with manufacturers, merchants, and brokers..." - Purchasing Principles and Practices by John Dinsmore, 1922, pp. 111 and 118

"...the purchasing executive is dependent upon his innate common sense for the successful accomplishment of his duties... Refuse to be a party to price beating... Avoid any method that even verges on sharp practice.. No longer is buying a leisurely process of obtaining goods at a low price, but a scientific system of securing quality, service, delivery and a fair price." - The Science of Purchasing by Helen Hysell, 1923, pp. 10, 32, and 39 
"Strange as it may seem, the actual prices paid for material, equipment, and supplies, frequently are of relatively minor importance. It is necessary to explain a statement so revolutionary, for, generally, price is about the only thing considered to be worthy of attention, and a difference of but a fraction of a cent per unit between two bids will shift the order or contract from one vendor to another, without proper evaluation of quality or utility with price." Principles of Scientific Purchasing, by Norman Harriman, 1928, pp. 16-17

"It has long been considered an essentially sound sales policy to develop goodwill on the part of customers toward the seller... Goodwill between a company and its suppliers needs to be just as assiduously cultivated... Failure to maintain these relations is often more serious than is sometimes believed." - Industrial Purchasing by Howard Lewis, 1940, p. 251

\section{SO, WHAT'S BEING SAID AFTER A DECADE OF REVERSE AUCTIONS}

As these ancient (by today's standards) thoughts have been relegated to the vault of history, it makes one wonder what the result has been of the extreme focus on driving down prices through the use of the reverse auction process has been. You don't have to go beyond the titles of some recent articles in practitioner oriented publications to get a sense of it. Here are some of those titles:

"E-nightmare: Online Reverse Auctions Offer Low Prices, Deliver Horror Stories"

"Reverse Auctions Destroy Relationships"

"The Big Squeeze"

"Material Handling Sellers Dragged into Reverse Auction Online Auctions"

In the interest of fairness, there are also many purchasers who are strongly convinced that the use of online reverse auctions has been a major driver of their dramatic cost reductions (see Guillemaud, et al, 2005). However, there has been empirical research that indicates numerous problems with this tool for both buyers and sellers. Emilani and Stec (2005) point to the finding in their survey of wood pallet suppliers that $60 \%$ of the suppliers seek ways to charge higher prices to their customers who require them to participate in online reverse auctions when circumstances allow it. This means that the cost savings the buyer realizes are often offset by future transactions that are not conducive to the use of reverse auctions. These suppliers overwhelmingly viewed online reverse auctions as a divisive practice that damages relationships with long-time customers. Most of the suppliers in the survey indicated that they drop out of the bidding process after one or two years of participation in reverse auctions as they feel that this tool is an unethical business practice. The major conclusion of this study was that the negatives of reverse auctions likely outweigh the positives for the buyers regularly using them.

\section{A PERSONAL CASE STUDY}

The author had a fascinating experience in 2004 on a visit to a Fortune 500 company. He had arranged for the "Strategic Sourcing" team to make a presentation to a group of his students about sourcing/purchasing/procurement and its role in this type of company. The senior member of the team had been with the company for about a year and made some opening remarks about his role and his background at another large company. He then turned the presentation over to two junior members of the team and they began to enthusiastically report on their use of an online reverse auction program. Over a period of about one hour, it became very evident that the senior member, who appeared to be in his mid- to late-50's was not really very enthused about the use of reverse auctions and felt it was going to do more harm than good over the long-term. There could not have been a greater contrast than with one of the junior members as she was so excited about past "accomplishments" of the reverse auction approach and its future potential that she became very evangelistic as she presented. Some of the MBA students in attendance asked her if she felt the users of products being acquired through the reverse auctions liked the approach. She admitted that many of them didn't as they felt they were not having adequate input into the choice of vendors. She went on to add that it was actually one of her goals to prevent 
“slick talking" salespeople from obtaining direct access to the users and "selling" them something they didn't need.

The author left the meeting that day wondering how long it would be before there was a major clash within the sourcing team. While not a psychologist, the author felt that the body language of the senior member indicated a high level of discomfort with the reverse auction approach.

\section{WHERE TO NOW? FUTURE RESEARCH}

While there have been several conceptual papers on this general topic within the past several years, there does not seem to have been a large scale empirical study of the issue surrounding the proliferation of reverse auctions. This would seem to indicate a need for studies of common practices since not everyone approaches the reverse auction in the same way. Which approaches seem to be working and which don't? Does the type of product strongly impact the success of the approach? What are the long-term effects on the pool of vendors and if the pool has shrunk, has the use of reverse auctions been scaled back or eliminated?

From the seller's side, do salespeople find it even more difficult than in years past to have an opportunity to get to the right people and to explain their value proposition? What kind of success have they experienced when they did not have the lowest bid/price? Have they learned any techniques to work around the reverse auction process and communicate with the people involved in the buying decision? Have they withdrawn from relationships with long-time customers due to reverse auctions? Do they do pre- and/or post-auction analyses of the profitability of specific customers?

It's obvious that there are numerous research projects that can be undertaken as part of a stream of studies of the use of reverse auctions. It will be interesting to see if these studies can be pursued and completed prior to the next shift in thinking in terms of how buyers and sellers will, or should, interact.

\section{REFERENCES}

1. Dinsmore, John, Purchasing Principles and Practices, 1922, pp. 111 and 118

2. Emilani, M.L. and D.J. Stec, Wood Pallet Suppliers' Reaction to Online Reverse Auctions, in Supply Chain Management: An International Journal, vol. 10, no. 4, ( 2005), pp. 278 - 288.

3. Giampietro, C. and M.L. Emilani, Coercion and Reverse Auctions, in Supply Chain Management: An International Journal, vol. 12, no. 2, (2007), pp. $75-84$.

4. Guillemaud, Wes, Ted Farris, Timothy G. Hawkins and Gene Roth, Reverse Auction Case Studies: Effectively and Ethically Lowering Supply Chain Costs, in the Proceedings of the $90^{\text {th }}$ Annual International Supply Management Conference, May 2005.

5. Harriman, Norman, Principles of Scientific Purchasing, 1928, pp. 16-17

6. Hysell, Helen, The Science of Purchasing, 1923, pp. 10, 32, and 39

7. Lewis, Howard, Industrial Purchasing, 1940, p. 251

8. Nagle, Thomas T. and John E. Hogan, The Strategy and Tactics of Pricing: A Guide to Growing More Profitably, Pearson-Prentice Hall, Upper Saddle River, NJ, 2006.

9. Rindsfoos, C. S., Purchasing, 1915, p. 1 